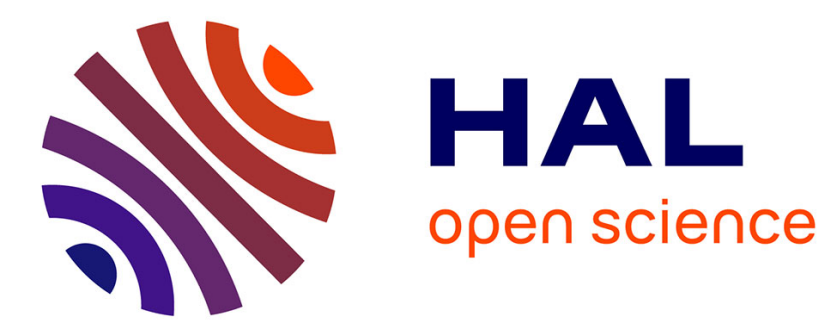

\title{
First report of extraordinary corkscrew gastropods of the genus Bulinus in Lake Malawi
}

Catharina Clewing, Bert Van Bocxlaer, Christian Albrecht

\section{To cite this version:}

Catharina Clewing, Bert Van Bocxlaer, Christian Albrecht. First report of extraordinary corkscrew gastropods of the genus Bulinus in Lake Malawi. Journal of Great Lakes Research, 2020, 46 (5), pp.1168-1175. 10.1016/j.jglr.2020.05.014 . hal-02917181

\section{HAL Id: hal-02917181 \\ https://hal.science/hal-02917181}

Submitted on 23 Nov 2020

HAL is a multi-disciplinary open access archive for the deposit and dissemination of scientific research documents, whether they are published or not. The documents may come from teaching and research institutions in France or abroad, or from public or private research centers.
L'archive ouverte pluridisciplinaire HAL, est destinée au dépôt et à la diffusion de documents scientifiques de niveau recherche, publiés ou non, émanant des établissements d'enseignement et de recherche français ou étrangers, des laboratoires publics ou privés. 
This manuscript has been accepted for publication in the Journal of Great Lakes Research. The DOI associated to this publication is: https://doi.org/10.1016/j.jglr.2020.05.014.

Title: First report of corkscrew gastropods of the genus Bulinus in Lake Malawi

Authors: Catharina Clewing ${ }^{1}$, Bert Van Bocxlaer ${ }^{2} \&$ Christian Albrecht ${ }^{1,3}$

\title{
Affiliations:
}

${ }^{1}$ Department of Animal Ecology and Systematics, Justus Liebig University Giessen, Giessen, Germany

${ }^{2}$ CNRS, Univ. Lille, UMR 8198 - Evo-Eco-Paleo, F-59000 Lille, France

${ }^{3}$ Department of Biology, Mbarara University of Science and Technology, Mbarara, Uganda

Corresponding author: Catharina.Clewing@allzool.bio.uni-giessen.de

\begin{abstract}
Open-coiled shells are rarely observed in gastropods, but they may occur at a relative frequency ranging from a small percentage of specimens in a population up to being specific to populations or even species. The origin of such corkscrew-like shells are poorly understood, but may include developmental anomalies, ecophenotypic plasticity or genetic inheritance. Here, we report the first case of gastropods from Lake Malawi with corkscrewlike shells, and we use comparative molecular studies with two mitochondrial gene fragments (COI and 16S rRNA) to examine its origin. The specimens belong to the genus Bulinus, more specifically to one of five clades of Bulinus recovered from the Malawi Basin. Beyond being seemingly specific to one of these Bulinus clades, network analyses indicate low genetic differentiation from the other, regularly shaped specimens in this clade. Although our results do not fully discard the possibility of corkscrew-like shells being genetically inherited or being caused by growth disturbance, their restrictive occurrence in a few geographically isolated populations in sympatry with specimens displaying a regular shell shape supports the hypothesis that the corkscrew-like shell shape in Bulinus are caused by ecophenotypic plasticity. For now, it is unclear whether aspects of the physical environment, or biotic interactions, such as a release from predation, caused the corkscrew-like morphotype. The phenomenon may
\end{abstract}


31 have been caused by the multiple environmental changes that Lake Malawi has been undergoing over recent 32 decades.

33

34 Key Words: ecophenotypic plasticity, ecological stress, shell-shape evolution, shell variability 


\section{Introduction}

Gastropod species occupy an iconic place in the faunas of many ancient lakes, both because of their high levels of endemism and their morphological disparity (see e.g. Brooks, 1950; Michel, 1994; Moore, 1898). Whether such morphological disparity has evolved by adaption and to what extent disparity in gastropod shell shape correlates with environmental conditions or the occupation of a diverse set of microhabitats are issues that are still highly debated in evolutionary biology and palaeontology (e.g. Annandale, 1924; Geary et al., 2002; Gorthner, 1992; Rasser and Covich, 2014; Van Bocxlaer, 2017; Vermeij and Covich, 1978). In short, gastropod shell shape figures prominently in the discussion about diversification dynamics in ancient lakes (Albrecht et al., 2010; Glaubrecht, 2008; Salzburger et al., 2014; Van Bocxlaer et al., 2008, 2020), but the utility of certain morphological traits is often poorly understood, especially for unique and unusual shell forms. Such phenotypes include, for example, the extraordinarily large aperture of Radix pinteri (Lymnaeidae) endemic to ancient Lake Prespa (Albrecht et al., 2008), long spines in Tiphobia horei (Paludomidae) endemic to Lake Tanganyika (Glaubrecht, 2008), strong ribs in Megalovalvata piligera nudicarinata (Valvatidae) endemic to Lake Baikal (Egorov, 2006), a keel made up of triangular segments in Angulyagra (Acanthotropsis) partelloi (Viviparidae) endemic to Lake Lanao (Bartsch, 1909), or (partly) openly coiled shell in Liobaicalia stiedae (Amnicolidae), Heleobia mirum (Cochliopidae), and Gocea ohridana (Hydrobiidae) endemic to lakes Baikal, Titicaca, and Ohrid, respectively (Hauffe et al., 2010; Kroll et al., 2012; Sitnikova et al., 2001). Open-coiling is a rare condition in which successive whorls, which are usually tightly coiled and overlapping, have become detached but are still coiled in a fairly uniform logarithmic spiral. The phenomenon gives shells a corkscrew-like appearance, and although it is infrequent among freshwater gastropods, such shell shapes appear in various taxa across marine, freshwater and terrestrial ecosystems around the globe (Clements et al., 2008; Clewing et al., 2015; Rex \& Boss, 1976). Sometimes corkscrew-like shells occur in a small proportion of specimens of a population, but in other cases open-coiling defines the shell shape of entire populations. Depending on the frequency of corkscrew-like shells the phenomenon is considered as a speciesspecific trait or as ecophenotypic modifications occurring sporadically among certain populations of a single species (Clewing et al., 2015; Table 1). By definition ecophenotypic changes are triggered by the environment, related to abiotic factors (e.g. changes in water chemistry; Rasser et al., 2014), ecological/physiological stress and/or biotic interactions (e.g. parasitism and predation; Zuykov et al., 2012).

Here, we report the first live-collected specimens of a freshwater gastropod from ancient Lake Malawi (Lake Niassa/Nyasa) that displays a corkscrew-like shell shape. This meromictic lake is located at the southern end of the western branch of the East African Rift System and of all African lakes it is in age (c. 5 Ma) and depth ( 700 m) only surpassed by Lake Tanganyika (Salzburger et al., 2014). The open-coiled specimens belong to the 
genus Bulinus, which is widespread in Africa and the Middle East (Brown, 1994). This genus is of great medical and veterinary interest because several of its species serve as intermediate hosts for blood flukes of the genus Schistosoma (Trematoda). These parasites are responsible for schistosomiasis, a debilitating tropical disease affecting humans and livestock (Brown, 1994). In Lake Malawi, four different Bulinus species occur, two of which are endemic to the lake (Albrecht et al., 2018): B. forskalii (B. forskalii group), B. globosus (B. africanus group), B. nyassanus (endemic; B. tropicus/truncatus complex), B. succinoides (endemic; B. tropicus/truncatus complex). Of these, B. globosus and B. nyassanus are known to transmit Schistosoma haematobium (Madsen et al., 2001; Marti et al., 1985) which causes human urinary schistosomiasis. This disease experienced an upsurge in incidence around the shorelines of Lake Malawi over recent decades (Van Bocxlaer et al., 2014).

We here used genetic data based on two mitochondrial markers to examine whether the corkscrew-like shells in Bulinus found in Lake Malawi may represent an ecophenotypic phenomenon or whether these individuals are genetically divergent from their regular-shaped relatives and may thus represent a potential new species. This question is also pertinent for other corkscrew-like specimens, such as those of Heleobia mirum from ancient Lake Titicaca, for which it remains uncertain whether they represent a valid species or result from hybridization, incomplete lineage sorting, ecophenotypic plasticity, or confused taxonomy (Kroll et al., 2012).

Given that few corkscrew Bulinus specimens were found, and that they occur in samples that also contained tightly coiled specimens, we hypothesize that their morphology reflects a growth disturbance or ecophenotypic plasticity. However, given that Lake Malawi is the only large lake on the African continent with endemic Bulinus species, including one that has colonized deep waters (Mandahl-Barth, 1972), we cannot exclude the possibility that the specimens represent a rare new species. We tested this hypothesis with phylogenetic and phylogeographical studies of various Bulinus populations throughout the Malawi Basin.

\section{Material \& Methods}

Sampling

Specimens of the freshwater gastropod genus Bulinus were collected in the Lake Malawi catchment in August 2006 by T. Geertz and R. Schultheiß, in October 2007 by T. Geertz and D. Simbeye, and in September 2014 by B. Van Bocxlaer from a total of 16 localities (see Fig. 1), they were preserved in $80 \%$ ethanol. The hitherto unknown specimens with a corkscrew-like shell (Fig. 2) were found during dredging at two close by locations (sites MW06 and MW07, 39 m depth; see Fig. 1) offshore Monkey Bay in the southern region of the Malawi Basin. These specimens were photographed with a digital microscope system (KEYENCE VHX-2000; KEYENCE Corp., Itasca, IL, USA). 
DNA isolation, PCR, and sequencing

Genomic DNA was extracted from a total of 29 specimens (including 4 specimens with an aberrant shell morph) using the CTAB protocol described by Wilke et al. (2006). We amplified two mitochondrial gene fragments, i.e. cyctochrome oxidase $c$ subunit I (COI, 390 bp length) and large ribosomal subunit (16S, 344-444 bp length) using the primers ASMIT1 and ASMIT2 (Stothard \& Rollinson, 1997) and 16Sar and 16Sbr (Palumbi et al., 1991), respectively. Polymerase chain reaction (PCR) was performed with the settings specified by Jørgensen et al. (2007). PCR products were sequenced on an ABI 3730 XL sequencer at LGC Genomics (Berlin, Germany) using the Big Dye Terminator Kit (Life Technologies). Vouchers (i.e., DNA, images, and shells) are stored in the Systematics and Biodiversity collection of the Justus Liebig University, Giessen (UGSB; see Table 2 for details).

\section{Dataset compilation and DNA alignment}

For comparison, our molecular dataset (26 COI and $1816 \mathrm{~S}$ sequences) was completed with sequences from NCBI GenBank (30 COI and 20 16S sequences; see Table 2). The final dataset consists of 57 specimens representing 21 nominal species (including the Lake Malawi endemics B. nyassanus and B. succinoides) and Bulinus spp. covering the total distribution range of the genus (Africa, Madagascar, and the Middle East). The planorbid Helisoma duryi was used as outgroup (COI: AY577513, 16S: AY577472).

The protein-coding COI gene fragment (390 bp) was aligned by eye using the sequence alignment editor BioEdit version 7.2.5 (Hall, 1999). The non-coding 16S gene fragment was aligned using the default settings of MAFFT as available at https://www.ebi.ac.uk/Tools/msa/mafft (Katoh and Standley, 2013) leaving a final alignment of $460 \mathrm{bp}$. Both fragments were concatenated for the subsequent phylogenetic analysis resulting in a final alignment length of $850 \mathrm{bp}$.

\section{Phylogenetic and phylogeographical analyses}

Phylogenetic relationships within Bulinus were reconstructed using Bayesian inference as implemented in MrBayes version 3.2.2 (Ronquist et al., 2012). The settings were chosen as follows: number of MCMC generations $=4,000,000 ;$ sample frequency $=100 ;$ burnin $=10,000(25 \%)$; number of runs $=2$. Partition-specific substitution models were selected using jModelTest version 2.1.4 (Darriba et al., 2012) based on the corrected Akaike information criterion (AICc). Accordingly, $\mathrm{HKY}+\mathrm{I}+\Gamma$ was selected for the $\mathrm{COI}$ partition and $\mathrm{GTR}+\mathrm{I}+\Gamma$ for the 16S partition. The effective sample size (ESS) of the parameters for both runs were checked on Tracer version 1.5 (Rambaut and Drummond, 2007). 

Bulinus specimens with a corkscrew-like shell (eight specimens in total) using TCS version 1.21 (Clement et al., 2000) with a connection limit of $95 \%$.

\section{Results \& Discussion}

In total, six specimens from two localities at the southern part of Lake Malawi (MW06 and MW07, see Fig. 1) displayed an aberrant corkscrew-like shell shape. Unfortunately, DNA was successfully amplified for only one (MW06/1) out of the four specimens (see Fig. 2) from which DNA was extracted. No DNA was extracted from the remaining two specimens because intact vouchers were required depending on the results of our study, i.e. in case our analyses would indicate a new species.

Bayesian inference on our dataset of 57 specimens representing 21 nominal species resulted in high ESS values $(>3,000)$ for all major parameters, which indicated that our runs attained stationary and that the analysis was robust. The resulting phylogeny reveals one highly-supported species complex (see Fig. 3A; A: $B$. truncatus/tropicus complex, posterior probability, PP 0.95) and three moderately to highly-supported species groups (see Fig. 3A, B: B. africanus group, PP 1.00; C: B. forskalii group, PP 0.90; and D: B. reticulatus group, PP 0.93), which is consistent with previous molecular phylogenetic studies on Bulinus (Jørgensen et al., 2007; Kane et al., 2008; Stothard et al., 2001; Tumwebaze et al., 2019). Accordingly, the B. africanus group forms a highly-supported (PP 0.99) sister to the B. forskalii group, which together are sister to the B. truncatus/tropicus complex (PP 0.95). The B. reticulatus group (here represented only by B. wrighti) is sister to all other groups/complexes (PP 1.00).

Our phylogeny revealed the existence of five clades/lineages from Lake Malawi (clades I.-V.; PP ranging from 0.67 up to 1.00; see Fig. 3A) and an additional B. globosus lineage from the Shire River (clade VI.; PP 0.53; see Fig. 3A). Four of the Lake Malawi lineages cluster within the B. truncatus/tropicus complex and the other lineage, i.e. B. globosus from Lake Malawi, clusters within the B. africanus group (see Fig. 3A). Interestingly, all lineages within the B. truncatus/tropicus complex seem to be monophyletic (partly with weak support) and consist of specimens only found in the lake, suggesting that these clades are potentially endemic to Lake Malawi. Moreover, our analyses reveal some geographical structure. Specimens of clade I and II were only found in the southern part of the lake (mainly around Monkey Bay) whereas clade III only in the north-western part (close to the city Karonga, see Fig. 1). Clade IV consists of an isolated specimen from the north that appears distinct from the well-supported clade III. However, based on the current dataset, we are not able to resolve the relationships 
B. truncatus/tropicus complex (see Fig. 3A), which also plagued earlier studies (Jørgensen et al., 2007; Stothard et al., 2001). Hence, further studies using high-resolution genome-wide loci based on next-generation sequencing techniques such RADseq (see e.g. Miura et al., 2019; Razkin et al., 2016) are required to better understand intrageneric relationships.

The phylogeny further revealed that the corkscrew-like specimen clusters within clade I (in the $B$. truncatus/tropicus complex). This clade is geographically constrained to the area of Monkey Bay, and it also contains specimens of $B$. nyassanus. Further examination of this clade with a statistical parsimony network analysis (see Fig. 3B), indicated that the specimen with corkscrew-like shell is separated from other specimens in clade I with regular shells by five to eight mutational steps. Phylogenetic and network analyses of clade I therewith indicate a short genetic distances between the specimen with corkscrew-like and those with regular shells, which suggests that growth deformation or ecophenotypic plasticity may have led to the observed shell variability. If the corkscrew-like shell morphology would be due to a general growth deformation, then we would expect to sporadically find Bulinus individuals with corkscrew-like shells across Bulinus populations, however, interestingly, all observed corkscrew-like Bulinus specimens have a very restricted geographical occurrence and they all occupy deep waters. Therefore, our data are most congruent with the hypothesis of ecophenotypic plasticity. Such plasticity may represent a possible response to habitat heterogeneity (Pigliucci, 2001; Schlichting \& Pigliucci, 1998) and it may even be a precursor to speciation (e.g. Pfennig et al., 2010). The cause of the observed plasticity is currently unknown, but it may relate to changes in water chemistry (Arter, 1989; Dunithan et al., 2012). Early embryonic exposure of Biomphalaria glabrata and Physa acuta to pharmaceutical chemicals has been demonstrated to result in open-coiling (Baynes et al., 2019). Unfortunately, detailed data on water chemistry and how it has changed over time are not available for the sampling sites examined. However, over the last 30 years, the human population density in Malawi has more than doubled and thus agricultural land use has significantly increased and affected lakeshore habitats (Van Bocxlaer et al., 2014). The consequences for ancient Lake Malawi are, among others, a gradual increase of sedimentation and eutrophication, especially in the south of the lake (Otu et al., 2011) where the corkscrew-like Bulinus specimens were found. Thus, alterations in the benthic ecosystem might explain ecophenotypic shell shape changes in Bulinus. However, given the limited frequency with which corkscrew-like Bulinus specimens have been found, other factors such as ontogenetic changes cannot be ruled out. Besides environmental parameters, parasites such as trematodes may be considered to have caused shell alterations (Krist, 2000; McCarthy et al., 2003). Interestingly, the Lake Malawi endemic B. nyassanus, which clusters within the same clade as the corkscrew-like Bulinus, is known to be the intermediate host for the urinary 
specimens were not found near the shoreline and because no macroparasites were observed during the preparation, the role of micro- and macroparasites remains uncertain.

The present study is based on very few specimens, and genetic data of a single specimen only, which is placed in an incompletely resolved phylogeny. Additional specimens and other genetic markers will need to be examined to verify the phylogenetic position of the corkscrew-like Bulinus specimens and whether they form a genetically distinct clade.

\section{Acknowledgments}

We thank T. Geertz, R. Schultheiß, and D. Simbeye for providing material. F. Chibwana and I. Tumwebaze are acknowledged for assistance in the laboratory. This study was funded by the Deutsche Forschungsgemeinschaft (SCHR352/9-1 and AL1076/6-2) and ANR-JCJC-EVOLINK.

\section{Author contributions}

$\mathrm{CC}$ and $\mathrm{CA}$ conceived the study. CC analysed molecular data. CC, CA, and BVB interpretated the results. CC drafted the initial manuscript. All authors have read and approved the final version of the manuscript.

\section{References}

Albrecht, C., Stelbrink, B., Clewing, C., 2019. Bulinidae P. Fischer \& Cross, 1880. In: Lydeard, C. \& Cummings, K.S. (eds.) Freshwater mollusks of the world. Johns Hopkins University Press, Baltimore, USA, 167-171.

Albrecht, C., Clewing, C., Kaunda, E., Mailosi, A., 2018. Bulinus nyassanus. The IUCN Red List of Threatened Species 2018: e.T3318A120114450. Downloaded on 20 January 2020.

Albrecht, C., Clewing, C., Kahwa, D., Magombo, Z.L.K., Kaunda, E., Mailosi, A., 2018. Bulinus succinoides. The IUCN Red List of Threatened Species 2018: e.T3320A122888722. Downloaded on 20 January 2020.

Albrecht, C., Clewing, C., Lange, C., 2018. Bulinus globosus. The IUCN Red List of Threatened Species 2018: e.T99504682A120114163. Downloaded on 20 January 2020.

Albrecht, C., Clewing, C. \& Lange, C., 2018. Bulinus forskalii. The IUCN Red List of Threatened Species 2018: e.T165794A120113860. Downloaded on 20 January 2020.

Albrecht, C., Vogel, H., Hauffe, T., Wilke, T., 2010. Sediment core fossils in ancient Lake Ohrid: testing for faunal change since the Last Interglacial. Biogeosciences 7, 3435-3446.

Albrecht, C., Wolff, C., Glöer, P., Wilke, T., 2008. Concurrent evolution of ancient sister lakes and sister 
species: the freshwater gastropod genus Radix in lakes Ohrid and Prespa. Hydrobiologia 615, 157-167.

Annandale, N., 1924. The evolution of the shell-sculpture in fresh-water snails of the family Viviparidae. Proc. R. Soc. London B 96, 60-76.

Arter, H.E., 1989. Effect of eutrophication on species composition and growth of freshwater mussels (Mollusca, Unionidae) in Lake Hallwil (Aargau, Switzerland). Aquat. Sci. 51, 87-99.

Basch, P.E., 1968. A scalariform Biomphalaria glabrata. Nautilus 82, 21.

Bartsch, P., 1909. Notes on the Philippine pond snails of the genus Vivipara, with descriptions of new species. Proc. United States Natl. Museum 37, 365-367.

Baynes, A., Montagut Pino, G., Duong, G. H., Lockyer, A. E., McDougall, C., Jobling, S., Routledge, E. J., 2019. Early embryonic exposure of freshwater gastropods to pharmaceutical 5-alpha-reductase inhibitors results in a surprising open-coiled "banana-shaped” shell. Sci Rep 9, 16439.

Boettger, C.R., 1949. Über das Auftreten einer erheblichen Schalenabweichung bei einer Posthornschnecke. Abh. Braunschw. Wiss. Ges. 1, 1-7.

Brooks, J.L., 1950. Speciation in ancient lakes. Q. Rev. Biol. 25, 30-60.

Brown, D.S., 1994. Freshwater snails of Africa and their medical importance. Taylor and Francis, London, 608 pp.

Brown, D.S., Shaw, K.M., Southgate, V.R., Rollinson, D., 1986. Bulinus guernei (Mollusca: Gastropoda) of West Africa: taxonomic status and role as host for schistosomes. Zool. J. Linn. Soc. 88, 59-90.

Burch, J.B., 1989. North American freshwater snails. Malacological Publications, Hamburg, Michigan, 365 pp. Clement, M., Posada, D., Crandall, K.A., 2000. TCS: a computer program to estimate gene genealogies. Mol. Ecol. 9, 1657-1659.

Clements, R., Liew, T.-S., Vermeulen, J. J., Schilthuizen, M., 2008. Further twists in gastropod shell evolution. Biol. Lett. 4, 179-182.

Clewing, C., Riedel, F., Wilke, T., Albrecht, C., 2015. Ecophenotypic plasticity leads to extraordinary gastropod shells found on the "Roof of the World". Ecol. Evol. 5, 2966-2979.

Darriba, D., Taboada, G.L., Doallo, R., Posada, D., 2012. jModelTest 2: more models, new heuristics and parallel computing. Nat. Methods 9, 772-772.

Dunithan, A., Jacquemin, S., Pyron, M., 2012. Morphology of Elimia livescene (Molluscs: Pleuroceridae) in Indiana, USA covaries with environmental variation. Am. Malacol. Bull. 30, 127-133.

Egorov, R., 2006. Treasure of Russian Shells. Supplement 4. Illustrated Catalogue with Selected Keys of the Recent Fresh- and Brackish-water Pectinibranch Molluscs (Gastropoda: Pectinibranchia) of Russia and 
Adjacent Areas. Colus-Doverie, 88 pp.

Geary, D.H., Staley, A.W., Müller, P., Magyar, I., Spring, N., 2002. Iterative changes in Lake Pannon Melanopsis reflect a recurrent theme in gastropod morphological evolution. Paleobiology 28, 208-221.

Glaubrecht, M., 2008. Adaptive radiation of thalassoid gastropods in Lake Tanganyika, East Africa: morphology and systematization of a paludomid species flock in an ancient lake. Zoosyst. Evol. 84, 71-122.

Gorthner, A., 1992. Bau, Funktion und Evolution komplexer Gastropodenschalen in Langzeit-Seen. Mit einem Beitrag zur Paläobiologie von Gyraulus “multiformis” im Steinheimer Becken. Stuttgarter Beiträge zur Naturkunde, Ser.B 190, 1-173.

Hall, T.A., 1999. BioEdit: a user-friendly biological sequence alignment editor and analysis program for Windows 95/98/NT. Nucleic Acids Symp. Ser. 41, 95-98.

Hauffe, T., Eross, Z., Albrecht, C., Schreiber, K., 2010. Gocea ohridana. The IUCN Red List of Threatened Species 2010: e.T155653A4815465. Downloaded on 20 January 2020.

Hirano, T., Saito, T., Tsunamoto, Y., Koseki, J., Ye, B., Do, V.T., Miura, O., Suyama, Y., Chiba, S., 2019. Enigmatic incongruence between mtDNA and nDNA revealed by multi-locus phylogenomic analyses in freshwater snails. Sci. Rep. 9, 6223.

Jørgensen, A., Jørgensen, L.V.G., Kristensen, T.K., Madsen, H., Stothard, J.R., 2007. Molecular phylogenetic investigations of Bulinus (Gastropoda: Planorbidae) in Lake Malawi with comments in the topological incongruence between DNA loci. Zoologica Scripta 36, 577-585.

Kane, R.A., Stothard, J.R., Emery, A.M., Rollinson, D., 2008. Molecular characterization of freshwater snails in the genus Bulinus: a role for barcodes?. Parasit Vectors 1, 15.

Katoh, K., Standley, D.M., 2013. MAFFT multiple sequence alignment software version 7: improvements in performance and usability. Mol. Biol. Evol. 30, 772-780.

Krist, A.C., 2000. Effect of the digenean parasite Proterometra macrostoma on host morphology in the freshwater snail Elimia livescens. J. Parasitol. 86, 262-267.

Kroll, O., Hershler, R., Albrecht, C., Terrazas, E.M., Apaza, R., Fuentealba, C., Wolff, C., Wilke, T., 2012. The endemic gastropod fauna of Lake Titicaca: correlation between molecular evolution and hydrographic history. Ecol. Evol. 2, 1517-1530.

Madsen, H., Bloch, P., Phiri, H., Kristensen, T.K., Furu, P., 2001. Bulinus nyassanus is an intermediate host for Schistosoma haematobium in Lake Malawi. Ann Trop Med Parasitol 95, 353-360.

Mandahl-Barth, G., 1973. Descriptions of new species of African freshwater molluscs. Proc. Malacol. Soc. London 40, 277-286. 
Marti, H.P., Tanner, M., Degremont, A.A., Freyvogel, T.A., 1985. Studies on the ecology of Bulinus globosus, the intermediate host of Schistosoma haematobium in the Ifakara area, Tanzania. Acta Trop. 42, 171-187.

McCarthy, H.O., Fitzpatrick, S.M., Irwin, S.W.S., 2003. Parasite alteration of host shape: a quantitative approach to gigantism helps elucidate evolutionary advantages. Parasitology $128,7-14$.

Michel, E., 1994. Why snails radiate: a review of gastropod evolution in long-lived lakes, both recent and fossil. In: Martens, K., Goddeeris, B., Coulter, G. (eds.), Speciation in Ancient Lakes. Arch. Hydrobiol. Beih. Ergebn. Limnol. 44, Stuttgart, 285-317.

Moore, J.E.S., 1898. On the hypothesis that Lake Tanganyika represents an old Jurassic sea. Q. J. Microsc. Sci. 41, 303-321.

Otu, M.K., Ramlal, P., Wilkinson, P., Hall, R.I., Hecky, R.E., 2011. Paleolimnological evidence of the effects of recent cultural eutrophication during the last 200 years in Lake Malawi, East Africa. J. Great Lakes Res. $37,61-74$.

Palumbi, S.R., Martin, A., Romano, S., McMillan, W.O., Stice, L., Grabowski, G., 1991. The simple fool's guide to PCR. University of Hawaii, Honolulu, 24 pp.

Pfennig, D.W., Wund, M.A., Snell-Rood, E.C., Cruickshank, T., Schlichting, C.D., Moczek, A.P., 2010. Phenotypic plasticity’s impacts on diversification and speciation. Trends Ecol. Evol. 25, 459-467.

Pigliucci, M., 2001. Phenotypic plasticity: beyond nature and nurture. Johns Hopkins Univ. Press, Baltimore, pp. 328.

Rambaut, A., Drummond, A.J., 2007. Tracer v. 1.5. Available from http://tree.bio.ed.ac.uk/software/tracer.

Rasser, M.W., 2014. Evolution in isolation: the Gyraulus species flock from Miocene Lake Steinheim revisited. Hydrobiologia 739, 7-24.

Rasser, M.W., Covich, A.P., 2014. Predation on freshwater snails in Miocene Lake Steinheim: a trigger for intralacustrine evolution? Lethaia 47, 524-532.

Razkin, O., Sonet, G., Breugelmans, K., Madeira, M.J., Gómez-Moliner, B.J., Backeljau, T., 2016. Species limits, interspecific hybridization and phylogeny in the cryptic land snail complex Pyramidula: the power of RADseq data. Mol. Phylogenet. Evol. 101, 267-278.

Rex, M. A., Boss, K. J., 1976. Open coiling in recent gastropods. Malacologia 15, 289-297.

Ronquist, F., Teslenko, M., Van Der Mark, P., Ayres, D.L., Darling, A., Höhna, S., Larget, B., Liu, L., Suchard, M.A., Huelsenbeck, J. P., 2012. MrBayes 3.2: efficient Bayesian phylogenetic inference and model choice across a large model space. Syst. Biol. 61, 539-542.

Salzburger, W., Van Bocxlaer, B., Cohen, A.S., 2014. Ecology and evolution of the African Great Lakes and 
Schlichting, C.D., Pigliucci, M., 1998. Phenotypic evolution. A reaction norm perspective. Sinauer Associates, Sunderland, Massachusetts, 387 pp.

Sitnikova, P., Röpstorf, P., Riedel, F., 2001. Reproduction, duration of embryogenesis, egg capsules and protoconchs of family Baicaliidae (Caenogastropoda) endemic to Lake Baikal. Malacologia 43, 59-85.

Stothard, J.R., Rollinson, D., 1997. Partial DNA sequences from the mitochondrial cytochrome oxidase subunit I (COI) gene can differentiate the intermediate snail hosts Bulinus globosus and B. nasutus (Gastropoda: Planorbidae). J. Nat. Hist. 31, 727-737.

Stothard, J.R., Brémond, P., Andriamaro, L., Sellin, B., Sellin, E., Rollinson, D., 2001. Bulinus species on Madagascar: molecular evolution, genetic markers and compatibility with Schistosoma haematobium.

Tumwebaze, I., Clewing, C., Dusabe, M.C., Tumusiime, J., Kagoro-Rugunda, G., Hammoud, C., Albrecht, C., of western Uganda with implications for the transmission of the Schistosoma haematobium group parasites. Parasit. Vectors 12, 565.

Van Bocxlaer, B., Albrecht, C., Stauffer Jr, J.R,. 2014. Growing population and ecosystem change increase human schistosomiasis around Lake Malawi. Trends Parasitol. 30, 217-220.

Van Bocxlaer, B., Ortiz-Sepulveda, C. M., Gurdebeke, P. R., Vekemans, X., 2020. Adaptive divergence is shell morphology in an ongoing gastropod radiation from Lake Malawi. BMC Evolutionary Biology 20, e5.

Van Bocxlaer, B., 2017. Hierarchical structure of ecological and non-ecological processes of differentiation shaped ongoing gastropod radiation in the Malawi Basin. Proc. R. Soc. B 284, 20171494.

Van Bocxlaer, B., Van Damme, D., Feibel, C.S., 2008. Gradual versus punctuated equilibrium evolution in the Turkana Basin molluscs: evolutionary events or biological invasions? Evolution 62, 511-520.

Vermeij, G.J., Covich, A.P., 1978. Coevolution of freshwater gastropods and their predators. Am. Nat. 112, 833843.

Wilke, T., Davis, G.M., Qiu, D., Spear, R.C., 2006. Extreme mitochondrial sequence diversity in the intermediate schistosomiasis host Oncomelania hupensis robertsoni: another case of ancestral polymorphism? Malacologia 48, 143-157.

Zuykov, M., Vinarski, M., Pelletier, E., Demers, S., Harper, D.A.T., 2012. Shell malformations in seven species of pond snail (Gastropoda, Lymnaeidae): analysis of large museum collections. Zoosyst. Evol. 88, 365368. 
346 Table 1. Selected taxa of recent freshwater gastropods showing corkscrew-like shells. Modified from Clewing et 347 al. (2015). *according to Albrecht et al. (2019).

\begin{tabular}{|c|c|c|c|}
\hline Family & Species & Location & Reference (plus shell shape) \\
\hline Ampularidae & Pomacea canaliculata ${ }^{\mathrm{B}}$ & inbred aquarium lineage & $\begin{array}{l}\text { B. Van Bocxlaer } \\
\text { pers. obs. }\end{array}$ \\
\hline Amnicolidae & Liobaicalia stiedae ${ }^{A}$ & $\begin{array}{l}\text { endemic to Lake Baikal, } \\
\text { Russia }\end{array}$ & ova et al., 2001 \\
\hline Bulinidae* $^{*}$ & Bulinus sp. ${ }^{B}$ & $\begin{array}{l}\text { Lake Malawi, Malawi } \\
\text { (Monkey Bay) }\end{array}$ & \\
\hline Cochliopidae & Heleobia mirum ${ }^{\mathrm{A}}$ & $\begin{array}{l}\text { endemic to Lake Titicaca, } \\
\text { Bolivia/Peru }\end{array}$ & t al., 2012 \\
\hline Hydrobiidae & Gocea ohridana ${ }^{A}$ & $\begin{array}{l}\text { endemic to Lake Ohrid, } \\
\text { Macedonia/Albania }\end{array}$ & lauffe e \\
\hline Lymnaeidae & Lymnaea stagnalis $^{\mathrm{B}}$ & $\begin{array}{l}\text { former USSR, Germany, } \\
\text { or USA }\end{array}$ & et al., 2012 \\
\hline Planorbidae & Anisus leucostoma ${ }^{\mathrm{B}}$ & Germany (laboratory) & Boettger, 1949 \\
\hline & Biomphalaria glabrata & Saint Lucia (laboratory) & Basch, 1968 \\
\hline & Gyraulus sp. ${ }^{B}$ & $\begin{array}{l}\text { Lake Bangong system, } \\
\text { Tibetan Plateau, China }\end{array}$ & Clewing et \\
\hline Valvatidae & $\begin{array}{l}\text { Valvata lewisi }{ }^{8} \\
\text { (morph ontariensis) }\end{array}$ & $\begin{array}{l}\text { Lake Superior drainage, } \\
\text { northwestern Ontario, Canada }\end{array}$ & 1989 \\
\hline
\end{tabular}

$348 \quad{ }^{\mathrm{A}}$ Corkscrew-like shell $=$ species-specific character.

$349{ }^{\mathrm{B}}$ Corkscrew-like shell = sporadic intraspecific trait. 
Table 2. List of studied specimens including taxon, specimen code, locality information, voucher number (stored 351 at the UGSB database), and GenBank accession numbers. Note that B. guerne $i$ is regarded as a synonym of $B$.

352 truncatus according to Brown et al. (1986). The outgroup taxon used for the phylogenetic analysis Helisoma duryi

353 (COI: AY577513, 16S: AY577472) is not listed here.

\begin{tabular}{|c|c|c|c|c|c|c|}
\hline Species & $\begin{array}{l}\text { Specimen } \\
\text { code }\end{array}$ & Location & Coordinates & $\begin{array}{l}\text { Voucher } \\
\text { no. }\end{array}$ & $\begin{array}{c}\text { GenBank } \\
\text { accession } \\
\text { no. COI }\end{array}$ & $\begin{array}{c}\text { GenBank } \\
\text { accession } \\
\text { no. } 16 \mathrm{~S} \\
\end{array}$ \\
\hline \multicolumn{7}{|c|}{ Bulinus truncatus/tropicus complex } \\
\hline 'B. guernei' & SN01.1 & Senegal & $\mathrm{N} / \mathrm{A}$ & & EU076716 & EU076725 \\
\hline B. hexaploidus & ET01.1 & Ethiopia & $\mathrm{N} / \mathrm{A}$ & & EU076717 & EU076723 \\
\hline B. liratus & MG01.1 & Madagascar & $\mathrm{N} / \mathrm{A}$ & & AF369590 & AY029543 \\
\hline B. natalensis & TZ01.1 & Tanzania & $\mathrm{N} / \mathrm{A}$ & & EU076719 & EU076730 \\
\hline \multirow[t]{2}{*}{ B. nyassanus } & MW01.1 & Malawi, Lake Malawi & $\mathrm{N} / \mathrm{A}$ & & AY577510 & AY577470 \\
\hline & MW02.1 & Malawi, Lake Malawi, Monkey Bay & $\mathrm{N} / \mathrm{A}$ & & AM921838 & - \\
\hline B. pemembraneus & KE01.1 & Kenya & $\mathrm{N} / \mathrm{A}$ & & EU076719 & EU076724 \\
\hline B. succinoides & MW03.1 & Malawi & $\mathrm{N} / \mathrm{A}$ & & EU076720 & EU076729 \\
\hline \multirow[t]{18}{*}{ Bulinus sp. } & MW04.1 & $\begin{array}{l}\text { Malawi, Nkhotakota, Lake Malawi } \\
\text { (shore) }\end{array}$ & $\begin{array}{l}-12.91953^{\circ} \mathrm{N} \\
34.30137^{\circ} \mathrm{E}\end{array}$ & $\begin{array}{l}\text { UGSB } \\
22267\end{array}$ & MT441583 & - \\
\hline & MW04.2 & $\begin{array}{l}\text { Malawi, Nkhotakota, Lake Malawi } \\
\text { (shore) }\end{array}$ & $\begin{array}{l}-12.91953^{\circ} \mathrm{N} \\
34.30137^{\circ} \mathrm{E}\end{array}$ & $\begin{array}{l}\text { UGSB } \\
22268\end{array}$ & MT441582 & МT396503 \\
\hline & MW05.1 & $\begin{array}{l}\text { Malawi, Karonga, Lake Malawi } \\
\text { (shore) }\end{array}$ & $\begin{array}{l}-9.89302^{\circ} \mathrm{N} \\
33.92841^{\circ} \mathrm{E}\end{array}$ & $\begin{array}{l}\text { UGSB } \\
22275\end{array}$ & MT441580 & МT396501 \\
\hline & MW06.1 & $\begin{array}{l}\text { Malawi, Monkey Bay, Lake } \\
\text { Malawi (offshore, } \sim 39 \mathrm{~m} \text { depth) }\end{array}$ & $\begin{array}{l}-14.05566^{\circ} \mathrm{N} \\
34.92276^{\circ} \mathrm{E}\end{array}$ & $\begin{array}{l}\text { UGSB } \\
22331\end{array}$ & MT441578 & MT396505 \\
\hline & MW07.1 & $\begin{array}{l}\text { Malawi, Monkey Bay, Lake } \\
\text { Malawi (offshore) }\end{array}$ & $\begin{array}{l}-14.04809^{\circ} \mathrm{N} \\
34.92171^{\circ} \mathrm{E}\end{array}$ & $\begin{array}{l}\text { UGSB } \\
22332\end{array}$ & - & - \\
\hline & MW07.2 & $\begin{array}{l}\text { Malawi, Monkey Bay, Lake } \\
\text { Malawi (offshore) }\end{array}$ & $\begin{array}{l}-14.04809^{\circ} \mathrm{N} \\
34.92171^{\circ} \mathrm{E}\end{array}$ & $\begin{array}{l}\text { UGSB } \\
23343\end{array}$ & - & - \\
\hline & MW07.3 & $\begin{array}{l}\text { Malawi, Monkey Bay, Lake } \\
\text { Malawi (offshore) }\end{array}$ & $\begin{array}{l}-14.04809^{\circ} \mathrm{N} \\
34.92171^{\circ} \mathrm{E}\end{array}$ & $\begin{array}{l}\text { UGSB } \\
23344\end{array}$ & - & - \\
\hline & MW08.1 & $\begin{array}{l}\text { Malawi, Karonga, Lake Malawi } \\
\text { (offshore, } \sim 11 \mathrm{~m} \text { depth) }\end{array}$ & $\begin{array}{l}-9.95860^{\circ} \mathrm{N} \\
33.94851^{\circ} \mathrm{E}\end{array}$ & $\begin{array}{l}\text { UGSB } \\
21855\end{array}$ & MT441568 & - \\
\hline & MW09.1 & $\begin{array}{l}\text { Malawi, Karonga, Lake Malawi } \\
\text { (offshore, 8 to } 16 \mathrm{~m} \text { depth) }\end{array}$ & $\begin{array}{l}-9.95873^{\circ} \mathrm{N} \\
33.94894^{\circ} \mathrm{E}\end{array}$ & $\begin{array}{l}\text { UGSB } \\
21858\end{array}$ & MT441567 & MT396492 \\
\hline & MW10.1 & $\begin{array}{l}\text { Malawi, Karonga, Lake Malawi } \\
\text { (offshore, 35 m depth) }\end{array}$ & $\begin{array}{l}-9.94955^{\circ} \mathrm{N} \\
33.95032^{\circ} \mathrm{E}\end{array}$ & $\begin{array}{l}\text { UGSB } \\
21861\end{array}$ & MT441579 & MT396500 \\
\hline & MW11.1 & $\begin{array}{l}\text { Malawi, Monkey Bay, Lake Malawi } \\
\text { (offshore, } 20 \mathrm{~m} \text { depth) }\end{array}$ & $\begin{array}{l}-14.05723^{\circ} \mathrm{N} \\
34.91818^{\circ} \mathrm{E}\end{array}$ & $\begin{array}{l}\text { UGSB } \\
21849\end{array}$ & MT441566 & - \\
\hline & MW12.1 & $\begin{array}{l}\text { Malawi, Monkey Bay, Lake Malawi } \\
\text { (offshore, 6 to } 10 \mathrm{~m} \text { depth) }\end{array}$ & $\begin{array}{l}-14.05163^{\circ} \mathrm{N} \\
34.91516^{\circ} \mathrm{E}\end{array}$ & $\begin{array}{l}\text { UGSB } \\
23345\end{array}$ & MT441576 & МT396499 \\
\hline & MW12.2 & $\begin{array}{l}\text { Malawi, Monkey Bay, Lake Malawi } \\
\text { (offshore, 6 to } 10 \mathrm{~m} \text { depth) }\end{array}$ & $\begin{array}{l}-14.05163^{\circ} \mathrm{N} \\
34.91516^{\circ} \mathrm{E}\end{array}$ & $\begin{array}{l}\text { UGSB } \\
23346\end{array}$ & MT441575 & MT396498 \\
\hline & MW12.3 & $\begin{array}{l}\text { Malawi, Monkey Bay, Lake Malawi } \\
\text { (offshore, } \sim 6 \text { to } 10 \mathrm{~m} \text { depth) }\end{array}$ & $\begin{array}{l}-14.05163^{\circ} \mathrm{N} \\
34.91516^{\circ} \mathrm{E}\end{array}$ & $\begin{array}{l}\text { UGSB } \\
23347\end{array}$ & MT441574 & МT396497 \\
\hline & MW12.4 & $\begin{array}{l}\text { Malawi, Monkey Bay, Lake Malawi } \\
\text { (offshore, } \sim 6 \text { to } 10 \mathrm{~m} \text { depth) }\end{array}$ & $\begin{array}{l}-14.05163^{\circ} \mathrm{N} \\
34.91516^{\circ} \mathrm{E}\end{array}$ & $\begin{array}{l}\text { UGSB } \\
23348\end{array}$ & MT441573 & MT396496 \\
\hline & MW13.1 & $\begin{array}{l}\text { Malawi, Chembe, Lake Malawi } \\
\text { (offshore, 2.5 m depth) }\end{array}$ & $\begin{array}{l}-14.03101^{\circ} \mathrm{N} \\
34.82889^{\circ} \mathrm{E}\end{array}$ & $\begin{array}{l}\text { UGSB } \\
23353\end{array}$ & MT441572 & - \\
\hline & MW13.2 & $\begin{array}{l}\text { Malawi, Chembe, Lake Malawi } \\
\text { (offshore, 2.5 m depth) }\end{array}$ & $\begin{array}{l}-14.03101^{\circ} \mathrm{N} \\
34.82889^{\circ} \mathrm{E}\end{array}$ & $\begin{array}{l}\text { UGSB } \\
23354\end{array}$ & MT441570 & МТ396493 \\
\hline & MW14.1 & $\begin{array}{l}\text { Malawi, Monkey Bay Lake Malawi, } \\
\text { (shore) }\end{array}$ & $\begin{array}{l}-14.07023^{\circ} \mathrm{N} \\
34.91713^{\circ} \mathrm{E}\end{array}$ & $\begin{array}{l}\text { UGSB } \\
23355\end{array}$ & MT441569 & - \\
\hline \multirow[t]{5}{*}{ B. truncatus } & CM01.1 & Cameroon & $\mathrm{N} / \mathrm{A}$ & & AF369747 & - \\
\hline & IR01.1 & Iran & $\mathrm{N} / \mathrm{A}$ & & EU076721 & EU076728 \\
\hline & SD01.1 & Sudan & $\mathrm{N} / \mathrm{A}$ & & AF369605 & - \\
\hline & MW15.1 & Malawi & $N / A$ & & AF369604 & AY029549 \\
\hline & CD01.1 & DR Congo & $\mathrm{N} / \mathrm{A}$ & & - & EU076726 \\
\hline
\end{tabular}




\begin{tabular}{|c|c|c|c|c|c|c|}
\hline \multirow[t]{3}{*}{ B. tropicus } & KE02.1 & Kenya & \multicolumn{2}{|l|}{$\mathrm{N} / \mathrm{A}$} & AF369602 & - \\
\hline & ZM01.1 & Zambia & \multicolumn{2}{|l|}{$\mathrm{N} / \mathrm{A}$} & AF369603 & - \\
\hline & ZW01.1 & Zimbabwe & \multicolumn{2}{|l|}{$\mathrm{N} / \mathrm{A}$} & EU076722 & EU076728 \\
\hline \multicolumn{7}{|c|}{ Bulinus africanus group } \\
\hline \multirow[t]{13}{*}{ B. globosus } & MW16.1 & $\begin{array}{l}\text { Malawi, Karonga, Lake Malawi } \\
\text { (beach pool, } 50 \mathrm{~m} \text { inland) }\end{array}$ & $\begin{array}{l}-9.89932^{\circ} \mathrm{N} \\
33.94370^{\circ} \mathrm{E}\end{array}$ & $\begin{array}{l}\text { UGSB } \\
21857\end{array}$ & MT441562 & MT396488 \\
\hline & MW16.2 & $\begin{array}{l}\text { Malawi, Karonga, Lake Malawi } \\
\text { (beach pool, } 50 \text { m inland) }\end{array}$ & $\begin{array}{l}-9.89932^{\circ} \mathrm{N} \\
33.94370^{\circ} \mathrm{E}\end{array}$ & $\begin{array}{l}\text { UGSB } \\
21856\end{array}$ & MT441563 & MT396489 \\
\hline & MW17.1 & Malawi, Liwonde, Shire River & $\begin{array}{l}-15.05699^{\circ} \mathrm{N} \\
35.22272^{\circ} \mathrm{E}\end{array}$ & $\begin{array}{l}\text { UGSB } \\
21845\end{array}$ & MT441564 & МT396490 \\
\hline & MW17.2 & Malawi, Liwonde, Shire River & $\begin{array}{l}-15.05699^{\circ} \mathrm{N} \\
35.22272^{\circ} \mathrm{E}\end{array}$ & $\begin{array}{l}\text { UGSB } \\
21846\end{array}$ & MT441565 & MT396491 \\
\hline & MW17.3 & Malawi, Liwonde, Shire River & $\begin{array}{l}-15.05699^{\circ} \mathrm{N} \\
35.22272^{\circ} \mathrm{E}\end{array}$ & $\begin{array}{l}\text { UGSB } \\
23338\end{array}$ & MT441584 & - \\
\hline & MW18.1 & $\begin{array}{l}\text { Malawi, Karonga, North Rukuru } \\
\text { River (estuary of Lake Malawi) }\end{array}$ & $\begin{array}{l}-9.90855^{\circ} \mathrm{N} \\
33.95027^{\circ} \mathrm{E}\end{array}$ & $\begin{array}{l}\text { UGSB } \\
23349\end{array}$ & MT441571 & MT396495 \\
\hline & MW18.2 & $\begin{array}{l}\text { Malawi, Karonga, North Rukuru } \\
\text { River (estuary of Lake Malawi) }\end{array}$ & $\begin{array}{l}-9.90855^{\circ} \mathrm{N} \\
33.95027^{\circ} \mathrm{E}\end{array}$ & $\begin{array}{l}\text { UGSB } \\
23350\end{array}$ & MT441587 & MT396504 \\
\hline & MW19.1 & $\begin{array}{l}\text { Malawi, Karonga, Lake Malawi } \\
\text { (beach pool, } 20 \text { m inland) }\end{array}$ & $\begin{array}{l}-9.93023^{\circ} \mathrm{N} \\
33.94670^{\circ} \mathrm{E}\end{array}$ & $\begin{array}{l}\text { UGSB } \\
23351\end{array}$ & MT441585 & МT396494 \\
\hline & MW19.2 & $\begin{array}{l}\text { Malawi, Karonga, Lake Malawi } \\
\text { (beach pool, 20 m inland) }\end{array}$ & $\begin{array}{l}-9.93023^{\circ} \mathrm{N} \\
33.94670^{\circ} \mathrm{E}\end{array}$ & $\begin{array}{l}\text { UGSB } \\
23352\end{array}$ & MT441586 & - \\
\hline & MW20.1 & $\begin{array}{l}\text { Malawi, Nkhata Bay, Lake Malawi } \\
\text { (shore) }\end{array}$ & $\begin{array}{l}-11.59727^{\circ} \mathrm{N} \\
34.30258^{\circ} \mathrm{E}\end{array}$ & $\begin{array}{l}\text { UGSB } \\
22256\end{array}$ & MT441577 & - \\
\hline & MW05.2 & $\begin{array}{l}\text { Malawi, Karonga, Lake Malawi } \\
\text { (shore) }\end{array}$ & $\begin{array}{l}-9.89302^{\circ} \mathrm{N} \\
33.92841^{\circ} \mathrm{E}\end{array}$ & $\begin{array}{l}\text { UGSB } \\
22274\end{array}$ & MT441581 & MT396502 \\
\hline & TZ02.1 & Tanzania & $\mathrm{N} / \mathrm{A}$ & & AF369595 & AY029546 \\
\hline & NE01.1 & Niger & $\mathrm{N} / \mathrm{A}$ & & AF369596 & - \\
\hline B. africanus & ZA01.1 & South Africa & $\mathrm{N} / \mathrm{A}$ & & AF369601 & - \\
\hline B. nasutus & TZ03.1 & Tanzania & $\mathrm{N} / \mathrm{A}$ & & AF369598 & AY029547 \\
\hline B. umbilicatus & NE02.1 & Niger & $\mathrm{N} / \mathrm{A}$ & & AF369600 & - \\
\hline B. obtusispira & MG02.1 & Madagascar & $\mathrm{N} / \mathrm{A}$ & & AF369588 & AY029542 \\
\hline \multicolumn{7}{|c|}{ Bulinus forskalii group } \\
\hline \multirow[t]{2}{*}{ B. forskalii } & TZ04.1 & Tanzania & $\mathrm{N} / \mathrm{A}$ & & AF369610 & AY029550 \\
\hline & MG03.1 & Madagascar & $\mathrm{N} / \mathrm{A}$ & & - & AY029545 \\
\hline B. crystallinus & AO01.1 & Angola & $\mathrm{N} / \mathrm{A}$ & & AF369742 & - \\
\hline B. bavayi & MG04.1 & Madagascar & $\mathrm{N} / \mathrm{A}$ & & AF369593 & AY029544 \\
\hline B. cernicus & MU01.1 & Mauritius & $\mathrm{N} / \mathrm{A}$ & & AF369613 & - \\
\hline B. scalaris & KE03.1 & Kenya & $\mathrm{N} / \mathrm{A}$ & & AF369740 & - \\
\hline B. senegalensis & ML01.1 & Mali & $\mathrm{N} / \mathrm{A}$ & & AF369745 & - \\
\hline \multicolumn{7}{|c|}{ Bulinus reticulatus group } \\
\hline \multirow[t]{2}{*}{ B. wrighti } & OM01.1 & Oman & $\mathrm{N} / \mathrm{A}$ & & AF369615 & AY029552 \\
\hline & FR01.1 & France, laboratory stock & $\mathrm{N} / \mathrm{A}$ & & AF369614 & - \\
\hline
\end{tabular}




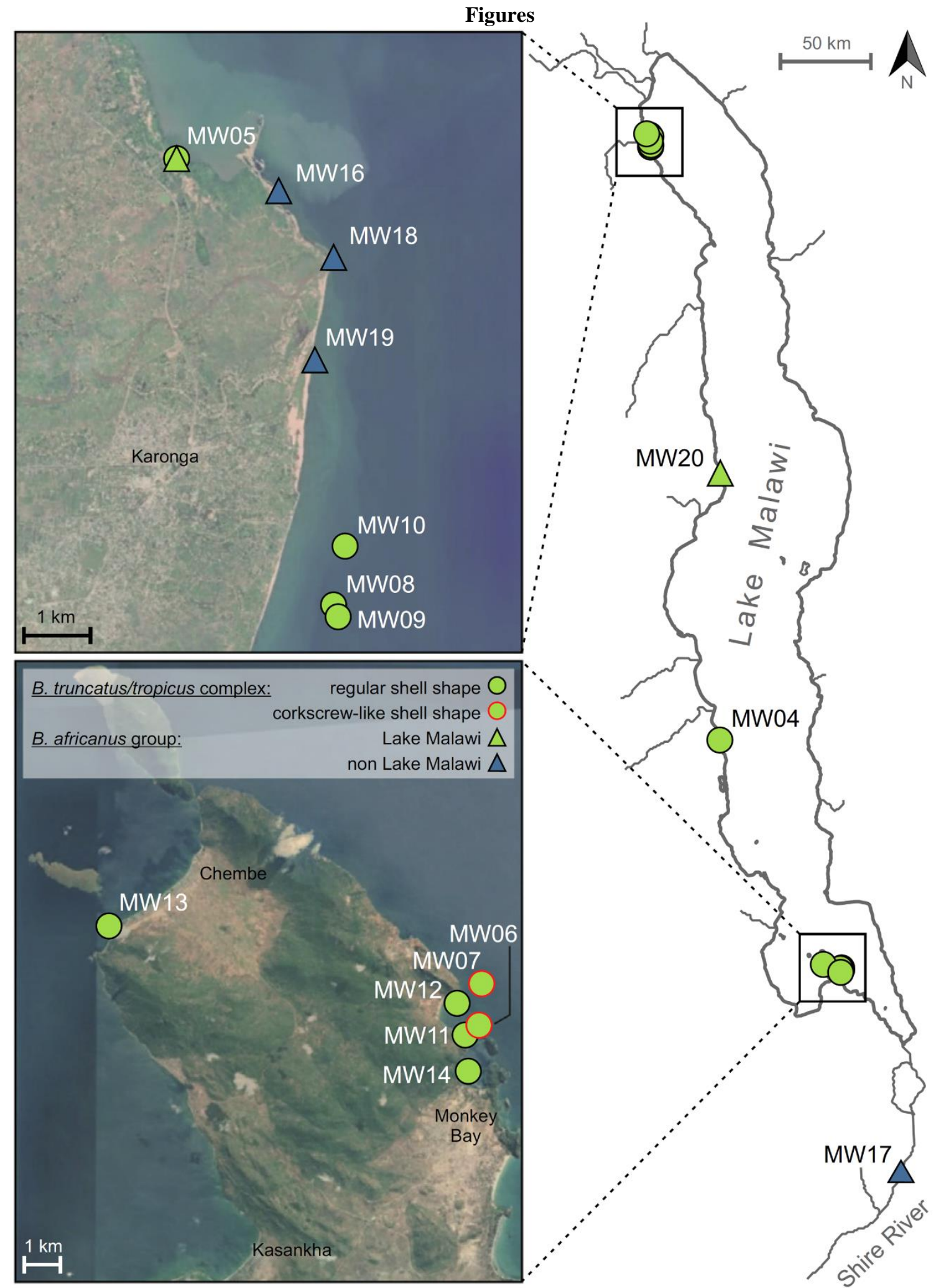

Figure 1. Sampling sites (with location codes, see Table 2) of Bulinus spp. at Lake Malawi and its catchment area.

Detailed locality information is given in Table 2. Location symbols either denote specimens belonging to the $B$. truncatus/tropicus complex (circles) or to the B. africanus group (triangles). Symbol colours indicate whether the site is located within Lake Malawi (green) or outside the main water body (blue). The two locations where corkscrew-like specimens were observed are highlighted with a red frame. 


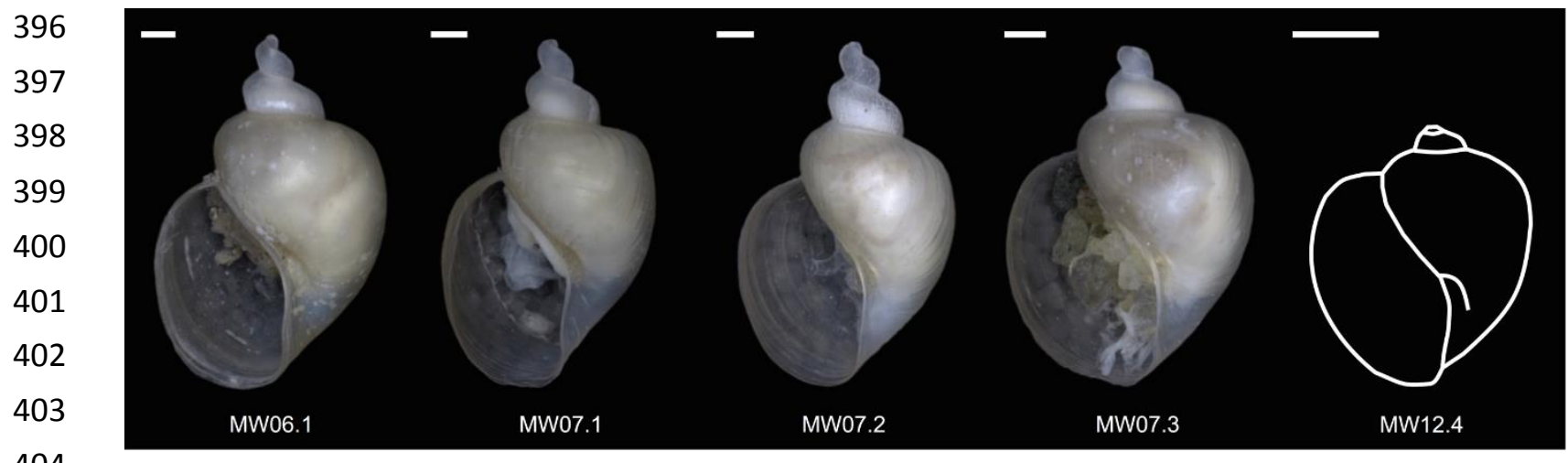

404

405 Figure 2. Specimens of Bulinus sp. from Lake Malawi with a corkscrew-like shell shape (specimens MW06.1,

406 MW07.1-3). The line drawing indicates a specimen with a regular shell for comparison (MW12.4; from a site 407 located nearby MW06 and MW07; see Fig. 1). Scale bar $=0.5 \mathrm{~mm}$. 
A $\longdiv { 0 . 0 9 }$

0.96 Bulinus sp. MW12.1

0.86 Bulinus sp. MW12.2

0.55 O B. nyassanus MW01.1

B. nyassanus MW02.1

0.67

O Bulinus sp. MW12.3

-O Bulinus sp. MW12.4

$0.96 \sqrt{ }$

Bulinus sp. MW11.1

Bulinus sp. MW06.1

B. truncatus CM01.1

D B. truncatus IR01.1

0.97

0.65 B. guernei SN01.1

B. hexaploidus ET01.1

B. truncatus SD01.1

B. pemembraneus KE01.1

O Bulinus sp. MW04.1

Bulinus sp. MW04.2

0.63 Bulinus sp. MW13.1

1.00 Bulinus sp. MW13.2

O B. succinoides MW03.1

O Bulinus sp. MW14.1

0.63 O Bulinus sp. MW10.1

1.00 Bulinus sp. MW09.1 0.95

O Bulinus sp. MW08.1

- B. liratus MG01.1

- B. tropicus KE02.1

- B. tropicus ZM01.1

- B. truncatus MW15.1

O Bulinus sp. MW05.1

B. natalensis TZ01.1

- B. tropicus ZW01.1

B. truncatus CD01.1

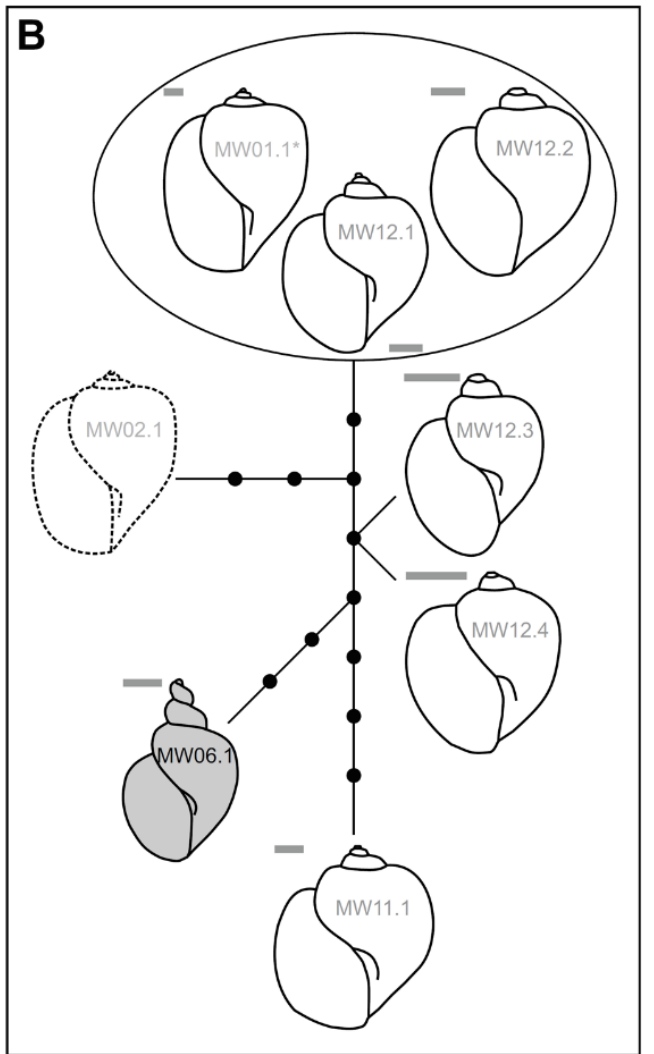

IIV.
0.93 B. globosus MW05.2

B. globosus MW16.2

B. globosus MW17.1

B B. globosus MW17.2

$\triangle$ B. globosus MW18.2

$\triangle$ B. globosus MW19.2

76 B. globosus MW201

B. globosus MW18.1

B. globosus

B. globosus MW16.

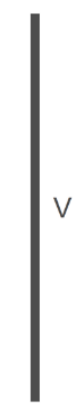

V

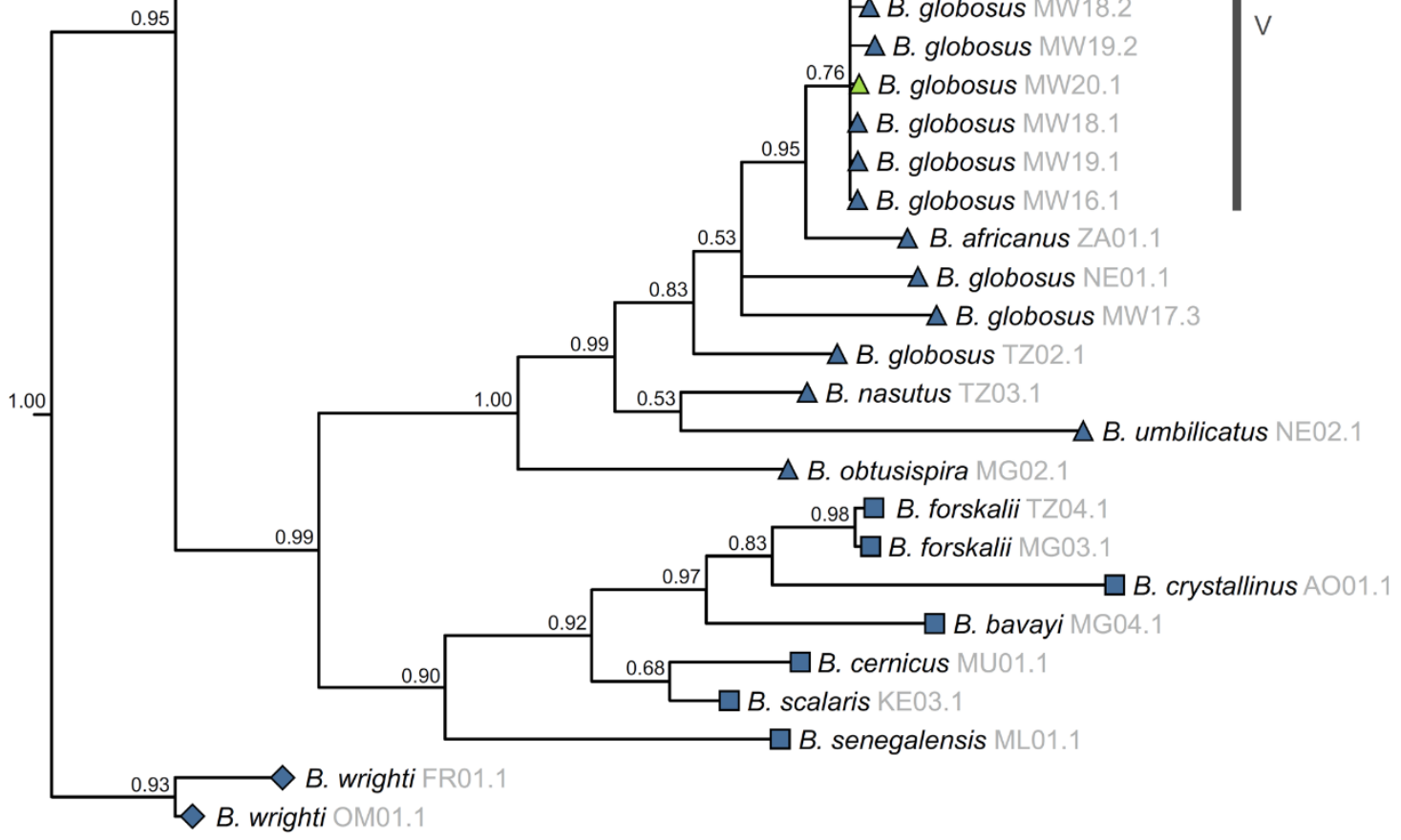

B. truncatus/tropicus complex: corkscrew-like shell shape, Lake Malawi regular shell shape, Lake Malawi non Lake Malawi $\bigcirc$

$\begin{array}{lr}\text { B. africanus group: } & \text { non Lake Malawi } \\ \text { B. forskalii group: } & \text { Lake Malawi } \\ \text { B. reticulatus group: } & \text { non Lake Malawi } \\ \end{array}$


450 Figure 3. (A) Phylogeny constructed with Bayesian inference of Bulinus spp. based on two mtDNA fragments 451 (COI and 16S). Helisoma duryi was used as outgroup but is not shown here. Specimens from Lake Malawi are 452 highlighted with green symbols, all non-Lake Malawi specimens with blue symbols (for the single specimen 453 marked with a white circle, detailed locality information are missing). While the symbols denote species groups 454 according to Stothard et al. (2001): circle - B. tropicus/truncatus complex; triangle - B. africanus group; square 455 B. forskalii group; rhomb - B. reticulatus group. Clades/lineages composed of Lake Malawi specimens are 456 indicated by dark-grey bars (I-VI). Bayesian posterior probabilities $(>0.50)$ are provided next to the nodes. (B) 457 Statistical parsimony network (connection limit: 95\%) of clade I-Bulinus specimens from Lake Malawi. 458 Haplotypes are illustrated with their shell shape, and the corkscrew-like specimen is again highlighted in grey. 459 Note that the shell shape of MW02.1 is replicated from MW01.1, because the specimen was not imaged and therefore it is illustrated with a dashed line. Scale bar $=0.5 \mathrm{~mm}$. 